\title{
The Effects of Celebrity Characteristics on Purchase Intentions: A Focus on Consumer Concern of Environmental Issues
}

\author{
Constanza Cespedes-Dominguez ${ }^{1}$ (D) , Cristobal Fernandez-Robin ${ }^{1, *}$ and Scott McCoy $^{2}$ \\ 1 Departamento de Industrias, Universidad Técnica Federico Santa María, Valparaíso 2090123, Chile; \\ constanza.cespede.12@sansano.usm.cl \\ 2 Mason School of Business, The College of William and Mary, Williamsburg, VA 23186, USA; \\ Scott.mccoy@mason.wm.edu \\ * Correspondence: cristobal.fernandez@usm.cl
}

check for

updates

Citation: Cespedes-Dominguez, C.; Fernandez-Robin, C.; McCoy, S. The Effects of Celebrity Characteristics on Purchase Intentions: A Focus on Consumer Concern of Environmental Issues. Sustainability 2021, 13, 4083. https://doi.org/10.3390/su13084083

Academic Editors: Ainsworth Bailey, Aditya Shankar Mishra and

Mojisola Tiamiyu

Received: 1 February 2021

Accepted: 24 March 2021

Published: 7 April 2021

Publisher's Note: MDPI stays neutral with regard to jurisdictional claims in published maps and institutional affiliations.

Copyright: (c) 2021 by the authors. Licensee MDPI, Basel, Switzerland. This article is an open access article distributed under the terms and conditions of the Creative Commons Attribution (CC BY) license (https:// creativecommons.org/licenses/by/ $4.0 /)$.

\begin{abstract}
Consumer awareness about environmental problems is important in guiding their purchasing decisions. The aim of this research is to validate the moderating effect of environmental concern in two relationships: between celebrity-brand congruity and attitudes toward the brand and, between celebrity-brand congruity and purchase intentions, specifically when consumers are exposed to green advertising including a celebrity endorser. The data were collected via an online survey with young North American and Chilean people. Structural equation modeling was used to test hypotheses in both samples. The results show that the only endorser characteristic relevant to the model is celebrity-brand congruity and its relationship with environmental concern $(\beta=0.23$ for North Americans and $\beta=0.35$ for Chileans with $p<0.05)$. In conclusion, the consumers evaluate congruence between celebrity and brand based on their concern about environment, then consider brand ethicality, and later brand credibility, which generates an attitude toward the brand and purchase intention. Therefore, identifying the consumers environmental concern is key to developing an effective advertisement with an appropriate celebrity. This research helps to understand the green-marketing literature in a more detailed way, due to this moderating variable capable of enhancing purchase intentions of consumers.
\end{abstract}

Keywords: environmental concern; moderator effect; green advertising; consumer behavior; structural equation modeling; purchase intention

\section{Introduction}

The global concern about environmental problems and societal pressure influence organizations to put their efforts toward green and sustainable business [1]. In recent years, green consumption has become a domain of interest for the business world as well as academicians and researchers [2]. The new consumption behaviors have generated challenges in marketing, which must develop new ecofriendly products and process. Today, environmentally committed business organizations are "greening" their manufacturing processes, developing "green" or "environmentally safe" products, and changing the way they do business [3].

The concept of green marketing was created in the first workshop named "Ecological Marketing" conducted by The American Marketing Association (AMA) in Chicago in 1975. According to Polonsky (1994) [4], defining green marketing is not a simple task, but it consists of all activities designed to generate and facilitate any exchanges intended to satisfy human needs or wants. Green advertising is one of the tools utilized in green marketing, and is on the rise, as an ever-increasing number of manufacturers are informing their consumers about pro-environmental aspects of their products and services [5]. Zinkhan and Carlson [6] defined green advertising as a marketing communication, which aims to fulfil the needs and wants of environmentally concerned people by incorporating messages around ecological, environmental friendliness and environmental sustainability. 
There are different resources used to create an effective advertising, and one of them is celebrity endorsement. One important aim of celebrity use is transmitting their image onto brands through advertising [7], by means of the meaning transfer model proposed by McCracken (1989) [8]. On the other hand, it is possible to understand celebrity's effects on consumers by means of S-O-R (Stimulus - Organism - Response) model, considering celebrity advertising as a stimulus [9]. Companies use celebrities to endorse their products and convince and persuade consumers to buy them. Applied to green advertising, if an endorser shares a brand's green image, the crafted congruence may amplify a product's selling point: its environmental value [10]. To create a green brand image, the endorser should thus have a pro-environmental image [11]. Pro-environmental celebrities have been found more effective in generating and stimulating favorable attitudes toward advertisement and brand and subsequently toward the intention to purchase the advertised product [12] Therefore, environmental concern of consumers is an important characteristic to consider in choosing an appropriate celebrity. Green consumerism has grown with people's rising environmental concern and according to an individual's level of involvement with the environment [10]. This research aims to contribute to the green-marketing literature by focusing on the moderating role of consumers' environmental concern, specifically by means of its relationship with celebrity-brand congruity and how this affects, indirectly, the attitudes toward the brand and purchase intentions. Therefore, green-marketing literature must consider environmental concern to be a key factor to persuade consumers on their purchase behavior.

This research is structured as follows: the next segment is a literature review, and the hypotheses are developed based on main variables. Subsequently, the materials and methods used explain the details of the sample, data collection, and measurements applied on survey. The subsequent section shows the results obtained by the structural equation modeling and hypothesis testing. Then, based on these results, a discussion about main topics is raised. The final part of the paper exposes conclusions and implications of the study, the limitations, and the scope of future research.

\section{Literature Review and Hypothesis Development}

\subsection{Brand Credibility}

Brand credibility refers to the "believability of the product position information contained in a brand, which depends on the willingness and ability of firms to deliver what they promise" [13]. Building brand credibility is a complex task that involves different strategies: for instance, demonstrating the right environmental information about its product and incorporated process.

When a brand has a high level of perceived expertise, trustworthiness, and attractiveness, consumers tend to evaluate the product positively. This is because high credibility reflects a higher quality, greater value, and worthiness of the product, leading to a more positive attitude from consumers [14].

Erdem et al. [13] investigated the effects of brand credibility on consumer choice across seven countries in Asia, Europe, and North and South America. As a result, they found that the general framework of brand credibility effects was empirically robust across the different countries studied, despite the minimum differences which credibility operated.

\subsection{Brand Ethicality}

According to Fan [15], an ethical brand is one that does not harm the public good but instead promotes it and when the brand has certain attributes such as honesty, integrity, diversity, responsibility, quality, respect, and accountability [16]. Financial criteria is not the only way to evaluate a brand [15]; nowadays, moral criteria is one of the most important criteria to assess how a firm is going to make the world a better place and thus contribute to adequate brand image building. Brands need to identify their appropriate functional and representational dimensions to ensure that they reflect consumers' needs in terms of the motivations for the ethical choices [17]. 


\subsection{Celebrity Characteristics}

A classic and useful definition about celebrity for this study is "any individual who enjoys public recognition and who uses this recognition on behalf of a consumer good by appearing with it in an advertisement" [8]. Recently, Arora et al. [18] in their research strongly supported the influence of celebrity on consumer's buying behavior. Celebrities that appear on green advertising generate an attractive message and thus a large impact on the brand [19] and influences consumer's attitude toward advertisements of green products $[12,20,21]$.

Kang and Choi [20] found that celebrity trustworthiness, celebrity ethicality, and celebrity-brand congruity significantly contribute to brand credibility and brand ethicality.

\subsubsection{Celebrity Trustworthiness}

Trustworthiness refers to the honesty and believability of an endorser, and it depends on target audience perceptions, that is to say, the extent to which he or she is perceived by consumers as honest and believable [22]. Spry, Pappu, and Cornwell [23] empirically show that the perceptions of endorsers' trustworthiness positively affect brand credibility. This analysis leads to our first hypothesis:

\section{Hypothesis 1. Celebrity trustworthiness positively affects brand credibility.}

Trustworthiness and ethicality are two similar concepts therefore it is possible to establish a link between them. Dubinsky, Nataraajan, and Huang [24] in their study about retail salespeople's ethical perceptions indicate that trustworthiness and ethical conduct go hand in hand. This study proposes a relationship between endorser trustworthiness and brand ethicality by means of the meaning transfer model proposed by McCracken [8], which postulates the transfer from celebrity endorser's image to that of the endorsed brand [20].

\section{Hypothesis 2. Celebrity trustworthiness positively affects brand ethicality.}

\subsubsection{Celebrity Ethicality}

Celebrity ethicality is defined as the extent to which a celebrity endorser is perceived as responsible, fair, and transparent. Although this meaning is similar to trustworthiness, the difference between them is while trustworthiness is associated to a celebrity's personality that can help him or her to be viewed as honest, ethicality is associated to his or her reputation for conscientiousness which is earned through actions and behavior [20]. Trudel and Cotte [25] in their research discovered that a product with green and ethical attributes in the marketplace is more likely to be taken into account by consumers at the purchase decision moment; therefore, a celebrity promoting this kind of product could improve brand credibility. On the basis of this analysis, our second hypothesis is proposed:

Hypothesis 3. Celebrity ethicality positively affects brand credibility.

No study has been found in which endorser ethicality and brand ethicality were examined simultaneously [20]. However, the meaning transfer model [7,21] supports a possible predictability of endorser ethicality to brand ethicality, because its premise is that the meanings perceived by consumer associated to celebrity is carried over to the endorsed brand. This analysis allows us to propose the following hypothesis:

Hypothesis 4. Celebrity ethicality positively affects brand ethicality. 


\subsubsection{Celebrity-Brand Congruity}

This variable is defined as "the degree of match between accessible endorser associations and attributes associated with the brand" [26]. This relationship between celebrity and brand is also understood by means of the match-up hypothesis, which means that celebrity image and product must be similar and matched-up in order for the advertisement to be effective [27]. When a product is advertised by a celebrity with suitable image that is highly relevant to the product, the confidence is higher on the advertisement and the celebrity compared to a product image promoted by a less famous, less relevant person [28]. In addition, Kang and Choi [20] indicate that the stronger a consumer feels this match, the more credible the consumer perceives the endorsed brand to be. Thus, we posit:

\section{Hypothesis 5. Celebrity-brand congruity positively affects brand credibility.}

When the celebrity chosen has a low ethical image, there would be incongruence between celebrity and brand; therefore, negative information or image could be transferred to the product or brand, decreasing the image brand [7,14,24].

\section{Hypothesis 6. Celebrity-Brand congruity positively affects brand ethicality.}

On the other hand, the stimulus-organism-response framework can also be applied to support these last two hypotheses, because it stablishes that environmental cues or stimuli affect the consumer's emotional state, which lead to their behavior being affected. Indeed, Min et al. [9] in their study found that celebrity-brand congruence positively influenced attitude toward the brand.

\subsection{Environmental Concern}

There are some definitions in the literature about this concept, one of them given by, Crosby, Gill, and Taylor [29], who described environmental concern as the respondent's concern about protecting the environment. Some years later, others explain it "as the degree to which people are aware of problems regarding the environment and support efforts to solve them and/or indicate a willingness to contribute personally to their solution" [30]. Nowadays, more people are concerned about environmental problems; thus, brands have the important task to develop sustainable products and promote them with the best strategies to be perceived by their customers as ethical. It is plausible that when a firm proclaims to deliver environmentally friendly products, the existing quality perceptions in the consumer's mind may positively influence them to enhance a greener brand image. Doszhanov and Ahmad [31] establish that a company reputation is significantly affected by green brand image, and positive brand image and company's reputation increase the customer's intention to use green products. According to the consumer's level of environmental concern, the answer may vary: that is, in comparison with the less environmentally conscious group, consumers with higher levels of environmental concern are more likely to engage in the pro-environmental behaviors because of their shared goals [32]. Chang, Zhang, and Xie [33] also suggest a similar analysis: that when consumers are highly concerned about environmental issues, a green advertisement is more likely to resonate with their dispositional tendencies to take the advertised issues seriously in contrast with those consumers who are not concerned about it. Recently, Yue et al. [34] found that enhancing consumers' environmental responsibility and environmental concern not only meets the green trends and the popular environmentalism of consumers but also increases their green consumption.

Kao and $\mathrm{Du}[35]$ in their study about the influence of green-advertising design and environmental emotion on advertising effect found that consumers' opinions on greenadvertising design is moderated by environmental emotions. The results are in line with previous literature, verifying that emotions play a moderating role in consumers' purchase intention. 
Blasche and Ketelaar [12] considered environmental concern as a moderator between celebrity-brand congruity and their effects on attitude toward the brand and purchase intention. Bamberg [36] suggests that environmental concern should not be viewed as a direct factor but as an important indirect factor, in influencing environmentally related behaviors; therefore, it is interesting to assess the moderator role of environmental concern. Thus, the following hypotheses are proposed:

Hypothesis 7. Celebrity-brand congruity is moderated by environmental concern.

Hypothesis 7a. Environmental concern will moderate the celebrity-brand congruence effects on attitude toward the brand and purchase intention by means of brand credibility.

Hypothesis $7 \mathbf{b}$. Environmental concern will moderate the celebrity-brand congruence effect on attitude toward the brand and purchase intention by means of brand ethicality.

An important challenge to brands is finding the way to communicate a relevant set of values to their consumers [17], mainly when the message is relevant to consumers or when it has an informative role. An appropriate communication could generate positive effects on consumer's behavior, for instance, enhancing or making a brand credible.

Kang and Hustvedt [37] suggest that the level of a company's transparency, especially in addressing sweatshop issues and/or labor conditions, can play a valid and significant role in building trust and positive attitude toward the company, as well as the extent to which consumer perceive these brand's characteristics. A positive consumer perceived ethicality of corporate brand is transferred into a positive evaluation of product brand trust. Therefore, this relationship is proposed in the following hypothesis:

Hypothesis 8. Brand ethicality positively affects brand credibility.

One way a brand can be considered to have brand ethicality is by having an ethical celebrity which generates positive effects on consumers behavior but in addition allows a brand to enhance its image.

J. J. Singh et al. [16] suggest that consumer-perceived ethicality positively impacts the product brand loyalty and thus can facilitate consumer retention, secure future purchases, and foster recommendation. Researchers have demonstrated that ethical business practices can drive consumer's positive brand attitudes $[11,28]$ and greater purchase intentions $[28,29]$. These obtained results allow us to propose the following hypothesis:

Hypothesis 9. Brand ethicality positively affects attitude toward the brand.

Hypothesis 10. Brand ethicality positively affects purchase intention.

Paul and Bhakar [38] and other prior studies found that brand credibility increases the probability of a product to be included in consumer's choice set. Moreover, past studies about brand credibility, found a strong relationship between the attitude toward advertisement, attitude toward the brand, and the resulting purchase intention of consumers [30-32]. These analyses allow us to propose the following hypothesis:

Hypothesis 11. Brand credibility positively affects attitude toward the brand.

Hypothesis 12. Brand credibility positively affects purchase intention.

In the green-advertising context, the environmental attitude of consumers has been reported as a major antecedent of pro-environmental behavior [39]. Therefore, brands need to be careful to give products and services to consumers based on their environmental requirements and thus generate a positive attitude toward the brand. Consequently, brand 
attitudes enhance purchase intentions among the consumers as their motivation gets increased [40].

Purchase intention (PI) is defined as the possibility of an individual to purchase a product/brand and has a strong link between perceptions and attitudes of consumers [41]: that is to say, they can change their decisions influenced by price, quality, and perceived value [42]. In the green-marketing context, when a consumer has purchase intentions by a specific green product or service, it is possible to talk about green consumption. It refers to a kind of consumption behavior which minimizes the negative impact of consumption on the environment in the whole process of purchase, use, and disposal [43]. The customer's attitude toward the brand is a predisposition that focuses on favorable or unfavorable impact on a specific brand after watching an advertisement of that brand [41]. When customers have more positive attitudes toward the brand, they are more likely to engage in green consumption [19]. On the other hand, it is important to consider that for this research, the advertisement includes a celebrity that enhance the message; therefore, the customer's positive attitude toward celebrity endorsement improves his/her purchase intention. [44]. In addition, previous studies proved that attitude toward the brand has a direct effect on purchase intention [18,45-48]. In this way, these analyses suggest proposing the following hypothesis:

Hypothesis 13. Attitude toward the brand positively affects purchase intention.

Each one of these hypotheses is represented by structural equation model proposed on Figure 1.

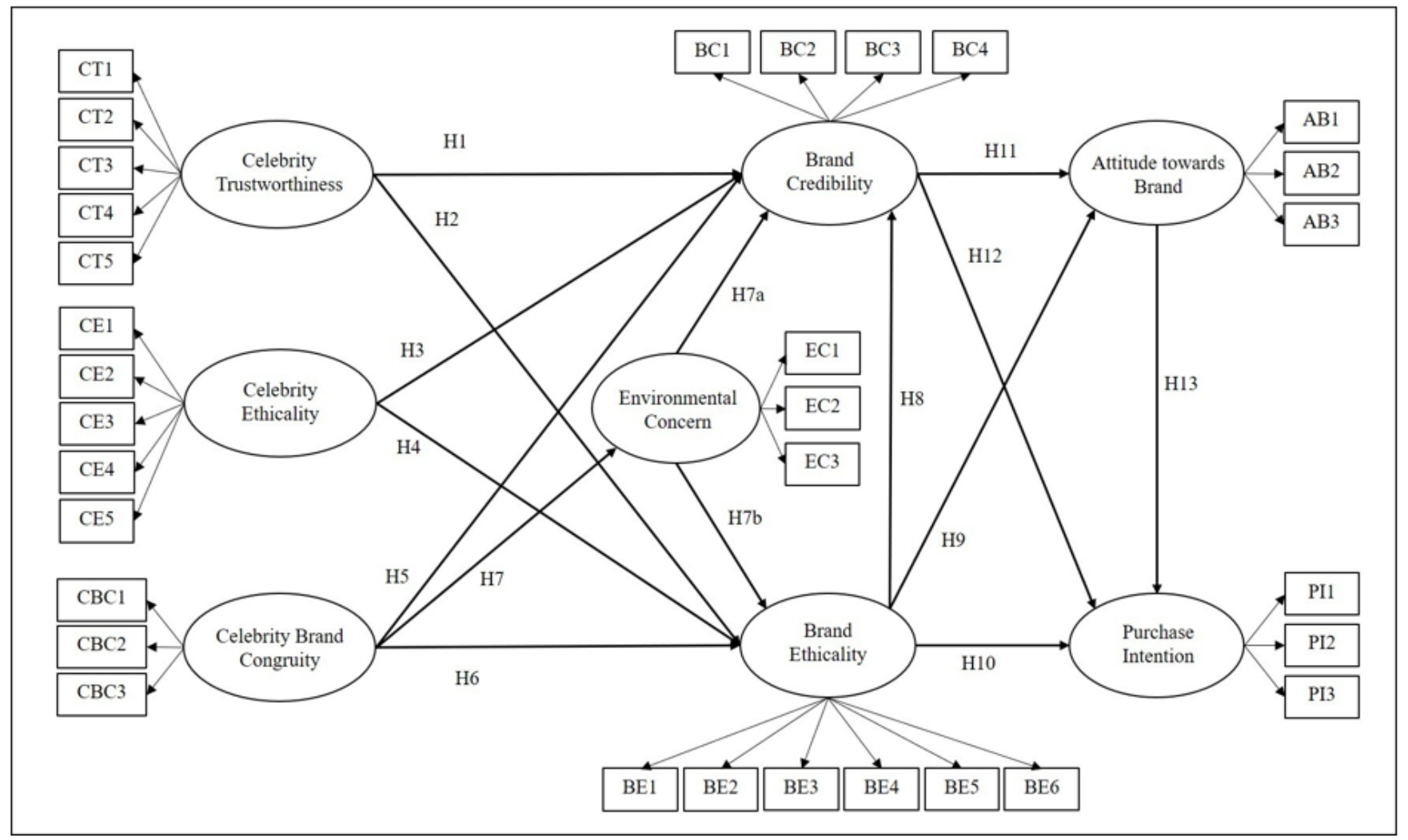

Figure 1. Structural equation model proposed.

\section{Materials and Methods}

The first step was looking for different ecofriendly brands that use an endorser celebrity on their advertisements to promote their products. Brands with this kind of advertising found were: The Honest Company with Jessica Alba, Urban Decay with Gwen 
Steffani and Ruby Rose, People Tree with Emma Watson, Juice Beauty with Gwyneth Paltrow, Feed with Jessica Alba and Anne Hathaway, and Beyond Meat with Snoop Dogg and Kevin Hart. These celebrities were applied on a pretest in order to identify the most famous and thus choose three of them to consider on the main survey. The pretest objective guaranteed that endorser celebrities used in the main survey are really known by respondents and thus avoids losing an answer for not knowing the celebrity used in green advertising.

\subsection{Sampling}

The online survey was conducted on young Chilean and North American consumers, mainly between 20 and 35 years old. We focused on this age range because they tend to have more concern about the green environment and influence their parents in purchasing decisions [49]. Data were collected with students at two medium-sized universities (one in Chile and one in the USA) by e-mails inviting them to participate in the survey. This sample with cultural differences allows us to make comparisons between young Chilean people' behavior and North American people' behavior about ecofriendly brands and how their environmental concern affects their attitudes, specifically when they face a green advertisement. A total of 465 consumers completed the survey. Of this total, only 366 responses were analyzed, because those responses from countries other than Chile and the United States were eliminated. Among that total, 194 were Chilean and 172 American. In both samples, the gender that predominated was female, with $52 \%$ for Chile and $56 \%$ for the United States. Statistics results of both samples can be reviewed in Table A1.

\subsection{Data Collection and Instruments}

As was mentioned above, a survey method was used to test the proposed hypothesis. At the beginning of the survey three real advertisements were exposed to the respondents, who had to choose one of them to answer the following questions. These advertisements were Emma Watson with People Tree, Snoop Dog with Beyond Meat, and Gwyneth Paltrow with Juice Beauty. These celebrities were chosen on a pretest as being the most famous endorsers.

\subsection{Measurements}

Questions on the main survey were developed to focus on four topics: celebrity characteristics measured by means of trustworthiness, ethicality, and brand congruity; brand image by means of brand ethicality and brand credibility; consumer attitudes by means of attitude toward the brand and purchase intention; and finally, environmental concern as the moderator variable.

Celebrity trustworthiness and celebrity ethicality as independent variables were employed using an adopted five-items scale by Ohanian [50] and a five-item scale based on the definitions of "ethics" from the American Marketing Association. Celebrity-brand congruity was employed on a three-item scaled adopted from [51]. Brand credibility was employed on a four-item scale from Newell and Goldsmith's [52] perceived corporate trustworthiness scale and slightly fit by Kang and Choi [20]. Brand ethicality was employed on a six-item consumer-perceived ethicality scale [53]. All these variables about celebrity credibility and brand image were measured on a seven-point Likert-type Scale ( $1=$ strongly disagree to $7=$ strongly agree). Attitudes toward the brand and purchase intentions were applied using three items, respectively, and a seven-point bipolar scale, adopted from Till and Busler's [51] study. All these variables were validated by Kang and Choi's [20] study. Environmental concern as a moderator was employed using a three-item scale validated by Blasche and Ketelaar [12] and Matthes and Wonneberger [54]. This variable was measured on seven-point Likert-type Scale too. Finally gender, country, age, education, and occupation were considered to be control variables [55,56]. All scales and items used on the survey were based on existing sources. 


\section{Results}

The different hypothesis set out in this study was tested by means of a structural equation model (SEM) with the objective to evaluate reliability and validity of the proposed model. This measurement model contains 8 latent variables and 32 observed variables. It is important to mention that this model was applied to the abovementioned groups in the same manner.

First, the structural model was tested using IBM SPSS Amos with maximum likelihood estimation. In both samples, the results obtained about factor loadings are positive. Garson (2012), Raubenheimer (2004), and Widaman (1993) [57,58] establish that to eliminate the collinearity between variables to the maximum, it is necessary to take the variables with factor loading $\geq 0.7$; therefore, it was not necessary to eliminate any observed variables. On the other hand, goodness-of-fit measures were checked, and they were slightly below established parameters. On both samples, goodness-of-fit index (GFI), adjusted goodnessof-fit index (AGFI), root mean square error of approximation (RMSEA), and normal fit index (NFI) are not in the validated range but close to it [59]. In order to enhance the model fit, modifications indeces (MI) were evaluated, specifically on covariances scores, and those values higher than 7.0, proposed in both samples, were included in the model [60]. With these modifications, the goodness-of-fit measures were effectively improved: Table 1 shows these indicators obtained before and after the model fit for both samples. However, there was no change in significant relationships or in their beta values $(\beta)$ with respect to the first CFA (Confirmatory Factor Analysis). Therefore, the proposed model remains as established before.

Table 1. Goodness-of-fit measurements of North American and Chilean sample.

\begin{tabular}{cccccc}
\hline & & $\begin{array}{c}\text { North Americans } \\
(\boldsymbol{n}=\mathbf{1 7 2})\end{array}$ & \multicolumn{2}{c}{$\begin{array}{c}\text { Chileans } \\
(\boldsymbol{n}=\mathbf{1 9 4})\end{array}$} \\
\hline Goodness-of-Fit Measures & $\begin{array}{c}\text { Recommended } \\
\text { Value }\end{array}$ & $\begin{array}{c}\text { Initial } \\
\text { Model }\end{array}$ & $\begin{array}{c}\text { Adjusted } \\
\text { Model }\end{array}$ & $\begin{array}{c}\text { Initial } \\
\text { Model }\end{array}$ & $\begin{array}{c}\text { Adjusted } \\
\text { Model }\end{array}$ \\
\hline $\begin{array}{c}\text { Minimum discrepancy } \\
\text { divided by its degree of } \\
\text { freedom (CMIN/DF) }\end{array}$ & $<5$ ó <3 & 1.883 & 1.814 & 1.727 & 1.654 \\
$\begin{array}{c}\text { Goodness of fit index (GFI) } \\
\text { Adjusted GFI (AGFI) }\end{array}$ & $0.9-1$ & 0.776 & 0.773 & 0.806 & 0.814 \\
$\begin{array}{c}\text { Root mean square residual } \\
\text { (RMR) }\end{array}$ & Close to 0 & 0.143 & 0.141 & 0.133 & 0.13 \\
$\begin{array}{c}\text { Root mean square error of } \\
\text { approximation (RMSEA) }\end{array}$ & $<0.05-0.08$ & 0.072 & 0.069 & 0.061 & 0.058 \\
$\begin{array}{c}\text { Comparative fit index (CFI) } \\
\quad \text { Normed fit index (NFI) }\end{array}$ & $0.9-1$ & 0.923 & 0.93 & 0.949 & 0.954 \\
Non-normed fit index (TLI) & $0.9-1$ & 0.851 & 0.857 & 0.887 & 0.893 \\
\hline
\end{tabular}

Next reliability analysis was measured via Cronbach's coefficient alpha $(\alpha)$ to check the internal consistency of the constructs [61]. It is important to mention that reliability analysis was conducted for each one of the samples, because this value could vary according to the sample studied [62]. Cronbach's alpha values between 0.7 and 0.95 conclude an acceptable reliability [63]. In this case, most of alpha values obtained in both samples were acceptable, just celebrity-brand congruity in Chilean sample and purchase intention in the North American sample were variables that exceed this range. Based on these results, the questionnaire was reviewed, specifically these two variables. It is possible to conclude that the questions for each variable are very similar to each other, which generated confusion in the respondents, thus providing redundant information between the items. On the other hand, composite reliability (CR) ranges from 0.83 to 0.96 in the Chilean sample and from 0.83 to 0.97 in the North American sample, in both cases values obtained exceed the recommended 0.7 [60].

Then, convergent validity was assessed to ensure that each latent variable was well represented by its indicators [64]. As a result of the second CFA with each one of the 
samples, all factor loadings were greater than the recommended 0.7 and therefore were statistically significant with $p$ value less than 0.05 . In addition, average variance extracted (AVE) was calculated for each one of latent variables and results ranged from 0.62 to 0.91 in the North American sample and from 0.62 to 0.88 in the Chilean sample. All average variance extracted were greater than 0.5 according to Fornell and Larcker [61] study. Descriptive, reliability, and validity measurement are exposed in Table 2.

Table 2. Reliability and validity measurement of North American and Chilean sample.

\begin{tabular}{|c|c|c|c|c|c|c|c|c|}
\hline \multirow[b]{2}{*}{ Constructs/Items } & \multicolumn{4}{|c|}{ North Americans $(n=172)$} & \multicolumn{4}{|c|}{ Chileans $(n=194)$} \\
\hline & $\begin{array}{c}\text { CFA } \\
\text { Loading }\end{array}$ & $\alpha$ & CR & AVE & $\begin{array}{c}\text { CFA } \\
\text { Loading }\end{array}$ & $\alpha$ & CR & AVE \\
\hline $\begin{array}{c}\text { Celebrity } \\
\text { Trustworthiness }\end{array}$ & & 0.93 & 0.94 & 0.75 & & 0.94 & 0.94 & 0.77 \\
\hline $\mathrm{CT} 1$ & 0.81 & & & & 0.76 & & & \\
\hline $\mathrm{CT} 2$ & 0.82 & & & & 0.86 & & & \\
\hline CT3 & 0.88 & & & & 0.91 & & & \\
\hline CT4 & 0.85 & & & & 0.89 & & & \\
\hline CT5 & 0.94 & & & & 0.92 & & & \\
\hline $\begin{array}{l}\text { Celebrity } \\
\text { Ethicality }\end{array}$ & & 0.88 & 0.90 & 0.64 & & 0.90 & 0.91 & 0.67 \\
\hline CE1 & 0.78 & & & & 0.78 & & & \\
\hline CE2 & 0.83 & & & & 0.85 & & & \\
\hline CE3 & 0.82 & & & & 0.82 & & & \\
\hline CE4 & 0.72 & & & & 0.82 & & & \\
\hline CE5 & 0.79 & & & & 0.79 & & & \\
\hline $\begin{array}{l}\text { Celebrity Brand } \\
\text { Congruity }\end{array}$ & & 0.95 & 0.95 & 0.87 & & 0.96 & 0.96 & 0.88 \\
\hline $\mathrm{CBC} 1$ & 0.89 & & & & 0.93 & & & \\
\hline CBC2 & 0.98 & & & & 0.95 & & & \\
\hline CBC3 & 0.94 & & & & 0.93 & & & \\
\hline Brand Credibility & & 0.94 & 0.94 & 0.81 & & 0.94 & 0.94 & 0.81 \\
\hline $\mathrm{BC} 1$ & 0.89 & & & & 0.82 & & & \\
\hline $\mathrm{BC} 2$ & 0.92 & & & & 0.93 & & & \\
\hline $\mathrm{BC} 3$ & 0.92 & & & & 0.93 & & & \\
\hline $\mathrm{BC} 4$ & 0.86 & & & & 0.91 & & & \\
\hline Brand Ethicality & & 0.91 & 0.91 & 0.64 & & 0.94 & 0.94 & 0.73 \\
\hline BE1 & 0.88 & & & & 0.89 & & & \\
\hline BE2 & 0.78 & & & & 0.83 & & & \\
\hline BE3 & 0.82 & & & & 0.91 & & & \\
\hline BE4 & 0.72 & & & & 0.82 & & & \\
\hline BE5 & 0.85 & & & & 0.91 & & & \\
\hline BE6 & 0.72 & & & & 0.78 & & & \\
\hline $\begin{array}{l}\text { Attitude toward } \\
\text { the Brand }\end{array}$ & & 0.90 & 0.90 & 0.76 & & 0.93 & 0.93 & 0.81 \\
\hline ATB1 & 0.84 & & & & 0.88 & & & \\
\hline ATB2 & 0.90 & & & & 0.89 & & & \\
\hline ATB3 & 0.87 & & & & 0.93 & & & \\
\hline Purchase Intention & & 0.96 & 0.97 & 0.91 & & 0.95 & 0.95 & 0.86 \\
\hline PI1 & 0.94 & & & & 0.91 & & & \\
\hline PI2 & 0.98 & & & & 0.96 & & & \\
\hline PI3 & 0.94 & & & & 0.9 & & & \\
\hline $\begin{array}{l}\text { Environmental } \\
\text { Concern }\end{array}$ & & 0.82 & 0.83 & 0.62 & & 0.83 & 0.83 & 0.62 \\
\hline EC1 & 0.78 & & & & 0.86 & & & \\
\hline $\mathrm{EC} 2$ & 0.76 & & & & 0.78 & & & \\
\hline EC3 & 0.83 & & & & 0.74 & & & \\
\hline
\end{tabular}




\section{Structural Model and Hypothesis Testing}

In the structural model, celebrity trustworthiness, celebrity ethicality, and celebritybrand congruity were defined as exogenous latent variables, while the other five variables were specified as endogenous latent variables. According to structural relationships between variables, with the North American sample 7 of 15 hypothesis proposed were statistically significant $(p<0.05)$, and with the Chilean sample, 6 of these 15 hypothesis were statistically significant too $(p<0.05)$. Analyzing results obtained with North American sample, relationship proposed between celebrity-brand congruity and environmental concern was supported (H7). In addition, environmental concern positively predicted brand ethicality (H7b), and the relationships between brand ethicality with brand credibility (H8), and the attitude toward the brand (H9) were supported too. Then, brand credibility predicted positive attitude toward the brand (H11) and purchase intention (H12). Finally, the relationship between attitude toward the brand and purchase intention was supported too. Regarding to the sample of young Chilean people, the validated hypotheses are the same except for hypothesis 11, which did not turn out to be statistically significant, although it is important to mention that its standardized regression weight was positive. Structural relationships are presented in Figures 2 and 3.

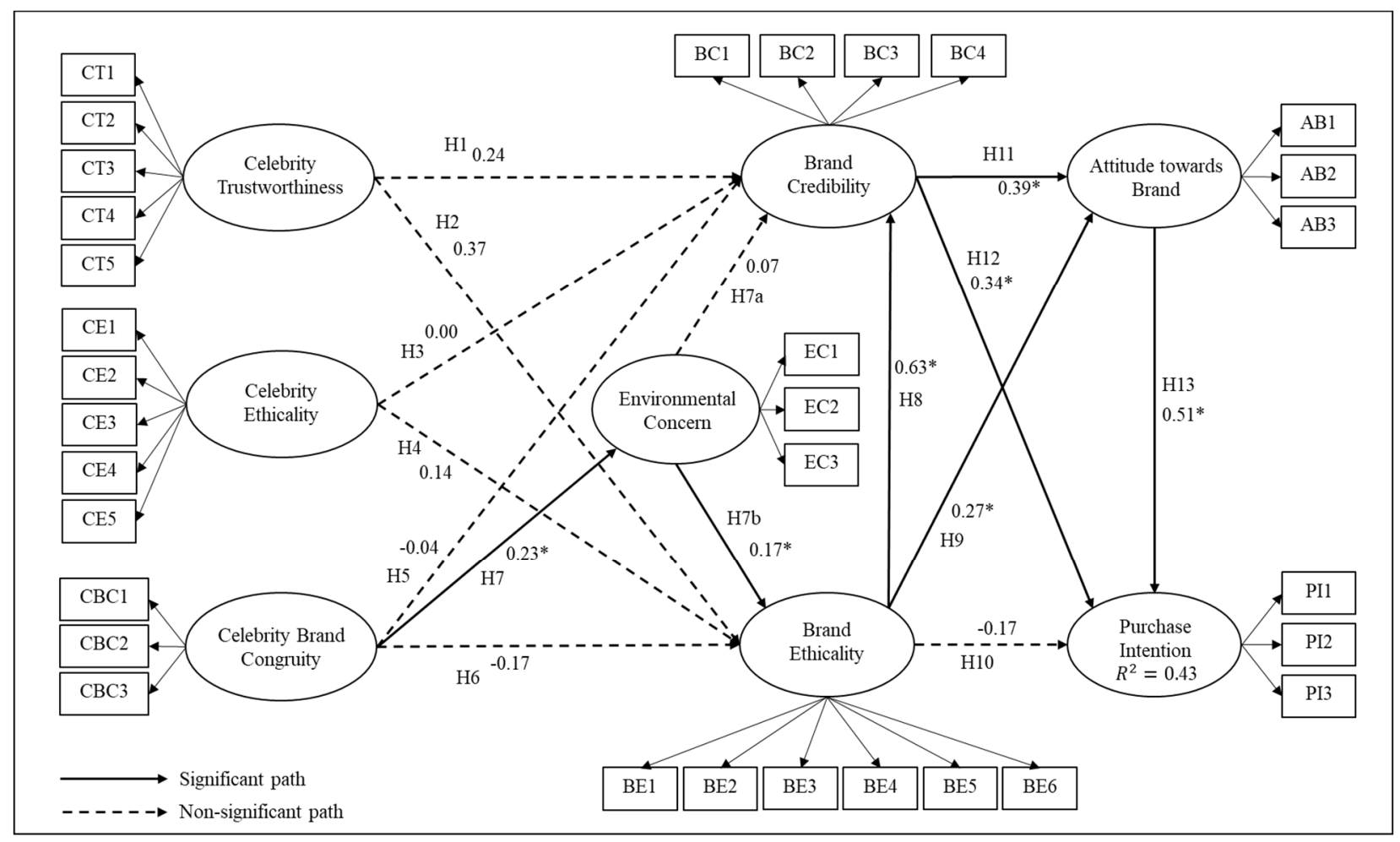

Figure 2. Structural equation model results with North American sample. Note. ${ }^{*} p<0.05$. 


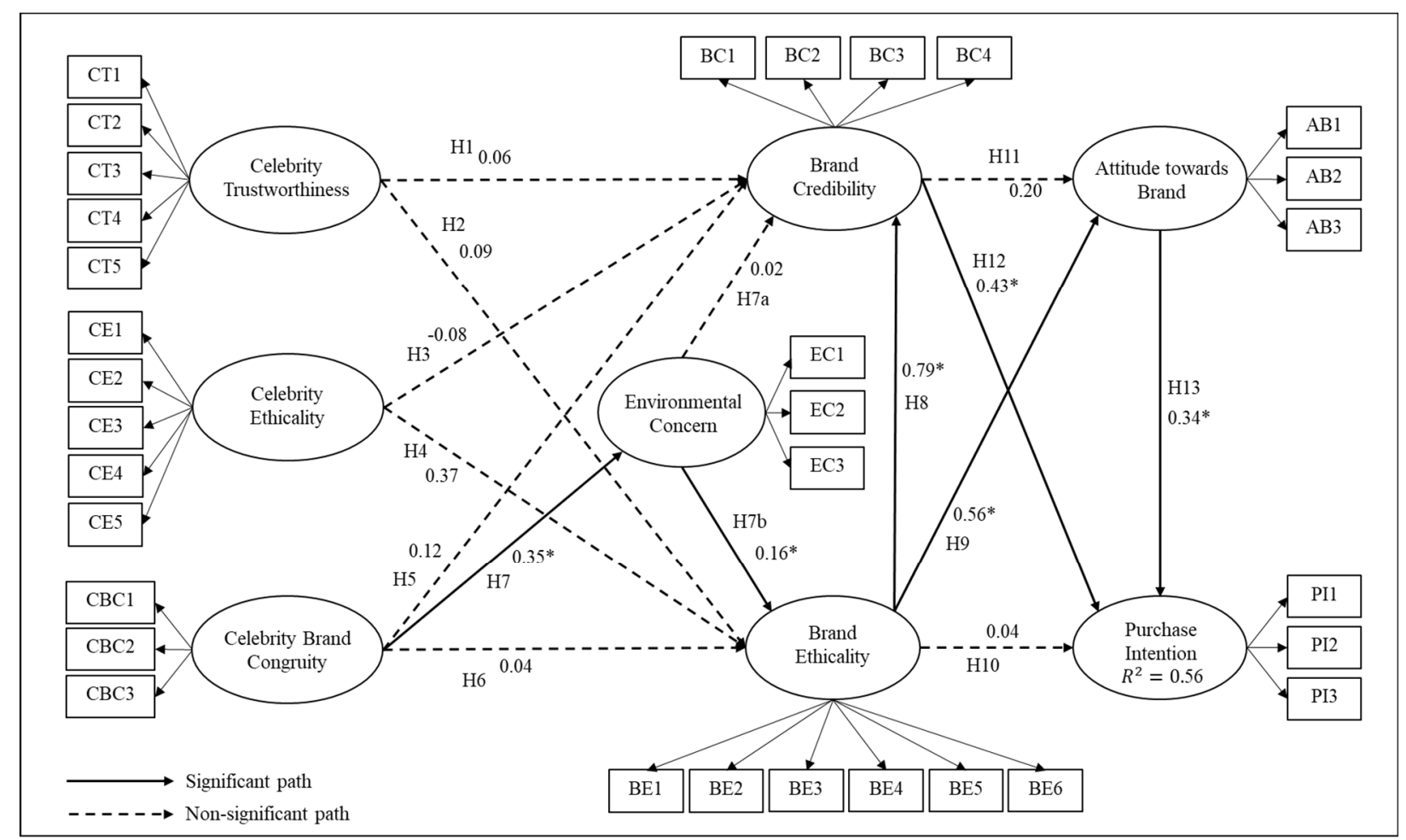

Figure 3. Structural equation model results with Chilean sample. Note. ${ }^{*} p<0.05$.

\section{Discussion}

Faced with environmental problems, consumers are concerned and are looking for different ways that avoid greater effects. This research focused on environmental concern as a moderator effect specifically on attitude toward the brand and purchase intention. Based on the obtained results, environmental concern effectively acts like a moderator and enhances the proposed model.

Regarding the North American sample, first, the respondents assign relevance to trust that celebrity transmits and its relationship with brand ethicality and brand credibility. These relationships have a beta value 0.36 and 0.25 respectively; however, they were not significant $(p>0.05)$. In Kang and Choi's [20] study, the same relationships resulted significant $(\beta=0.11 ; p<0.01)$.

On the other hand, respondents also assess celebrity ethicality and its relationship with the ethic and credibility of the brand. Again, the relationships are nonsignificant $(\beta=-0.02$ and $0.16, p>0.05)$, unlike other studies where relationship between celebrity ethicality and brand ethicality is significant $(\beta=0.21 ; p<0.01)$.

Third, celebrity-brand congruity neither generates significant relationships with brand image $((\beta=-0.04$ with brand credibility and -0.17 with brand ethicality, $p>0.05)$ contrary situation to Kang and Choi's [20] study ( $\beta=0.15$ with brand credibility and 0.44 with brand ethicality, $p<0.01)$.

It is important to mention that the aim of this study is to evaluate moderator effect of environmental concern between celebrity-brand congruity and consumer behavior; therefore, all insignificant relationship recently mentioned allow us to validate environmental concern like moderator variable. All in all, the most important relationship is between celebrity-brand congruity and environmental concern $(\beta=0.23 ; p<0.05)$.

Environmental concern is related with the rest of the model by means of its direct and significant relationship with brand ethicality. This analysis is validated with Suki [65] study, where the direct relationship between environmental concern and purchase intention is nonsignificant $(\beta=0.005 ; p>0.05)$. It is important to consider that in the right side of the 
model all the routes are significant except for hypothesis 10 . If the celebrity chosen on green advertising has a great congruence with the brand, environmental concern positively moderates its effect to the other variables by means of different routes to achieve a high purchase intention. The route with the greatest positive effects includes celebrity-brand congruity, environmental concern, brand ethicality, brand credibility, attitude toward the brand, and finally purchase intention. This route explains $43 \%$ of the variance. As was mentioned above, the only way to positively affect purchase intention is with the relationship between celebrity-brand congruity and environmental concern.

On the other hand, the environmental concern of the young Chilean people in evaluating the celebrity on green advertising just by its congruence with the brand even this relationship $(\beta=0.35 ; p<0.05)$ is higher than relationship obtained with young North Americans. Therefore, once again there is a moderating effect of environmental concern. With this variable included in the model, all the other significant relationships are the same as the previous case, except for the direct relationship between brand credibility and attitude toward the brand (H11). In this case all the results obtained are better, and purchase intention explains the data's variance with $56 \%$. In conclusion, the environmental concern of consumers is an important variable to consider in the model because it is the only one that significantly relates a celebrity characteristic with consumer behavior. Consumers first asses if the delivered message is or not a good option for them, especially if the combination of the brand and celebrity goes together according to their criteria $(0.98 ; 0.95)$. Then, environmental concern is mainly influenced by observed variable that consider consumer's sacrifices to protect the environment. From this congruence and level of concern, consumers assess brand ethicality, mainly influenced by the brand's moral norms respect $(0.88 ; 0.89)$. After this ethic evaluation, brand credibility is generated by consumers, strongly affected by two observed variables: if the brand makes trustful claims $(0.85 ; 0.87)$ and if the brand is honest $(0.85 ; 0.86)$. Finally, if all the relationships are positive, attitude toward the brand and purchase intention increases, as a consequence of a favorable and positive evaluation of the brand on advertising $(0.9 ; 0.93)$ and the fact that consumers definitely would consider purchasing the brand products $(0.98 ; 0.96)$, respectively.

\section{Conclusions}

This research examines the moderating effect of consumers' environmental concern on purchase intention and attitude toward the brand, specifically when they face a green advertising with a celebrity.

By incorporating environmental concern in the model as a moderator variable, it happens that, of the proposed relationships between the characteristics of the celebrity and the brand image, none of them is significant: that is, none of the three characteristics of the celebrity can predict the ethicality or credibility of the brand $(\mathrm{H} 1, \mathrm{H} 2, \mathrm{H} 3, \mathrm{H} 4, \mathrm{H} 5$, and $\mathrm{H} 6$ are rejected). The only one significant relationship to highlight in this part of the model is between celebrity-brand congruity and environmental concern. Therefore, this variable effectively acts as a moderator of the celebrity effects on consumer behavior, which is in line with Blasche and Ketelaar study [12], but it is also capable of inhibiting the other proposed celebrity relationships, thus generating a simplified model and a conclusion that had not been previously discovered.

Environmental concern, as a moderator variable of the celebrity effects on consumer behavior, acts by an indirect relationship, including brand ethicality and then brand credibility. Therefore, this find reject studies that propose it with a direct relationship [47,65].

Prior studies demonstrate that environmental concern level of consumers is rather the level of evaluating when they face a green advertising, but the present study proves that independent of environmental concern level, the key characteristic to consider on future models focused on green advertising is the congruence between brand and celebrity.

According to celebrity characteristics, it is interesting note that Kumar and Tripathi [42] in their research also evaluate green advertising with a celebrity as a promoting resource and its effects on consumer behavior. They evaluate the celebrity credibility through three 
observed variables; however, none of them measures the congruence between the brand and the celebrity. Nonetheless, this study proposes a simplified model that allows for the same measuring but through the moderating act of environmental concern.

\subsection{Theoretical Implications}

One of the most important contributions of this research to green-marketing literature is considering environmental concern as a moderator variable. Although the model proposes three characteristics of the celebrity, the only one that generates a significant impact on the model is celebrity-brand congruity, which is directly connected to the moderating variable. This relationship allows that the environmental concern moderates the effects of celebrity on attitude toward the brand and purchase intention.

In addition to being a moderator, this variable simplifies the proposed model and thus allows an efficient application for future analysis. This is because its incorporation in the model prevents the generation of significant relationships between the celebrity and the brand image. Therefore, an efficient application of this model is not to consider trustworthy and ethics of the celebrity since they are variables that do not contribute to the model. In addition, the model can be further simplified given the non-significance between brand ethics and purchase intention, a relationship that cannot be justified in this study and Kang and Choi study [20].

On the other hand, the findings between samples contribute to understand that the congruency effect holds mainly for consumers with a higher level of environmental concern [33]. However independent of this concern level, the most important characteristic of celebrity to consider is his/her congruence with the brand promoted.

\subsection{Practical Implications}

The results obtained in this research give to brand managers a structural equation modeling of easy application to choose the right celebrity to appear on green advertising. Marketing agents should identify the environmental concern of consumers and thus choose the celebrity that includes all the characteristics that allow her/him to be similar or congruent with the brand and thus be able to get more use out of it as a promoting resource.

This study is in line with prior studies that argue that celebrity congruence when coupled with the attitude toward the brand showed higher purchase intention. This may be considered to be an important cue for the marketers in planning their marketing efforts endeavoring positive purchase intentions [18]

Although knowing a consumer's level of environmental concern is key for the impact on the brand and purchase intention, it is important to also consider that brand image cannot be forgotten because it could decrease the positive effects of the relationship between celebrity-brand congruity and environmental concern.

\section{Limitations and Future Research}

One of the main limitations of this research is about the advertising used on the questionnaire. Respondents had to choose between three real green advertisement and each one of them with a celebrity. The researchers gave the option to choose one of these green advertising to ensure that the respondent knows about the celebrity on it and is able to answer regarding his/her image. However, this situation could have influenced the obtained responses, because in real life, consumers watch different kinds of green advertising: they assess more than one and compare between them before deciding.

On the other hand, the celebrity-brand congruity and purchase intention variables were evaluated by means of questions with measurement levels very similar between them; therefore, this generated confusion on the respondents. This situation could improve by changing the measurement items or adding other questions that allow for a better understanding of the variable. 
Effectively environmental concern acts like a moderator variable; therefore, the constructs used to measure it could be improved to obtain more accurate information about consumer's concern and possibly thus increase Cronbach's alpha result of this variable.

Author Contributions: C.C.-D. and C.F.-R. participated in all the phases and contributed equally to this work. S.M. participated in data acquisition, writing-review and editing. All authors have read and agreed to the published version of the manuscript.

Funding: This research received no external funding.

Institutional Review Board Statement: This research was reviewed by IRB-Institutional review board-to make sure there is no harmful parts to humans participating.

Informed Consent Statement: Inform consent was obtained from all subjects involved in the study.

Data Availability Statement: Data available on request due to restrictions eg privacy or ethical. The data presented in this study are available on request from the corresponding author. The data are not publicly available due to there is personal information about the respondents.

Conflicts of Interest: The authors declare no conflict of interest.

\section{Appendix A}

Table A1. Statistics results of North American and Chilean sample.

\begin{tabular}{|c|c|c|c|c|}
\hline \multirow[b]{2}{*}{ Constructs/Items } & \multicolumn{2}{|c|}{ North Americans $(n=172)$} & \multicolumn{2}{|c|}{ Chileans $(n=194)$} \\
\hline & Media & SD & Media & SD \\
\hline \multicolumn{5}{|l|}{ Celebrity } \\
\hline \multicolumn{5}{|l|}{ Trustworthiness } \\
\hline $\mathrm{CT} 1$ & 4.31 & 1.57 & 5.19 & 1.70 \\
\hline CT2 & 4.69 & 1.55 & 5.58 & 1.54 \\
\hline CT3 & 4.44 & 1.50 & 5.34 & 1.67 \\
\hline CT4 & 4.53 & 1.60 & 5.44 & 1.51 \\
\hline CT5 & 4.32 & 1.51 & 5.40 & 1.66 \\
\hline \multicolumn{5}{|l|}{ Celebrity } \\
\hline \multicolumn{5}{|l|}{ Ethicality } \\
\hline CE1 & 4.24 & 1.66 & 4.94 & 1.86 \\
\hline CE2 & 4.68 & 1.33 & 5.37 & 1.47 \\
\hline CE3 & 4.90 & 1.49 & 5.71 & 1.54 \\
\hline CE4 & 4.70 & 1.59 & 5.59 & 1.51 \\
\hline CE5 & 4.69 & 1.40 & 5.17 & 1.61 \\
\hline \multicolumn{5}{|l|}{$\begin{array}{l}\text { Celebrity Brand } \\
\text { Congruity }\end{array}$} \\
\hline CBC1 & 3.99 & 1.53 & 5.49 & 1.62 \\
\hline $\mathrm{CBC} 2$ & 4.10 & 1.77 & 5.37 & 1.72 \\
\hline CBC3 & 4.17 & 1.74 & 5.25 & 1.74 \\
\hline \multicolumn{5}{|l|}{ Brand } \\
\hline \multicolumn{5}{|l|}{ Credibility } \\
\hline $\mathrm{BC} 1$ & 4.71 & 1.32 & 5.18 & 1.41 \\
\hline $\mathrm{BC} 2$ & 4.83 & 1.28 & 5.34 & 1.41 \\
\hline BC3 & 4.85 & 1.28 & 5.27 & 1.37 \\
\hline BC4 & 4.54 & 1.26 & 5.25 & 1.57 \\
\hline \multicolumn{5}{|l|}{ Bran Ethicality } \\
\hline BE1 & 5.10 & 1.23 & 5.48 & 1.41 \\
\hline BE2 & 4.88 & 1.34 & 5.32 & 1.54 \\
\hline BE3 & 5.19 & 1.33 & 5.50 & 1.42 \\
\hline $\mathrm{BE} 4$ & 4.78 & 1.34 & 5.22 & 1.53 \\
\hline BE5 & 5.05 & 1.25 & 5.30 & 1.42 \\
\hline BE6 & 4.80 & 1.28 & 5.13 & 1.50 \\
\hline
\end{tabular}


Table A1. Cont.

\begin{tabular}{clccc}
\hline & \multicolumn{2}{c}{ North Americans $(\boldsymbol{n}=\mathbf{1 7 2})$} & \multicolumn{2}{c}{ Chileans $(\boldsymbol{n}=\mathbf{1 9 4})$} \\
\hline Constructs/Items & Media & SD & Media & SD \\
\hline $\begin{array}{c}\text { Attitude toward } \\
\text { the Brand }\end{array}$ & & & \\
ATB1 & 4.97 & 1.19 & 5.53 & 1.19 \\
ATB2 & 5.07 & 1.20 & 5.63 & 1.18 \\
ATB3 & 5.12 & 1.18 & 5.75 & \\
\hline Purchase & & & & 1.24 \\
Intention & & & & 1.39 \\
PI1 & 4.22 & 1.70 & 5.24 & 1.52 \\
PI2 & 4.18 & 1.55 & 5.25 & \\
PI3 & 4.27 & 1.65 & 5.24 & 0.84 \\
\hline Environmental & & & & 0.87 \\
Concern & & & 5.64 & 0.91 \\
EC1 & 5.16 & 1.09 & 5.64 & \\
EC2 & 4.70 & 1.29 & 5.59 & \\
EC3 & 4.87 & 1.12 & & \\
\hline
\end{tabular}

\section{References}

1. Leonidou, C.N.; Leonidou, L.C. Research into Environmental Marketing/Management: A Bibliographic Analysis. Eur. J. Mark. 2011, 45, 68-103. [CrossRef]

2. Bailey, A.A.; Mishra, A.S.; Tiamiyu, M.F. Application of GREEN Scale to Understanding US Consumer Response to Green Marketing Communications. Psychol. Mark. 2018, 35, 863-875. [CrossRef]

3. Alniacik, U.; Yilmaz, C. The Effectiveness of Green Advertising: Influences of Claim Specificity, Product's Environmental Relevance and Consumers' pro-Environmental Orientation. Amfiteatru Econ. J. 2012, 14, 207-222.

4. Polonsky, M.J. An Introduction to Green Marketing. Electron. Green J. 1994, 51, 51-2628. [CrossRef]

5. Banerjee, S.; Gulas, C.S.; Iyer, E. Shades of Green: A Multidimensional Analysis of Environmental Advertising. J. Advert. 1995, 24, 21-31. [CrossRef]

6. Zinkhan, G.M.; Carlson, L. Green Advertising and the Reluctant Consumer. J. Advert. 1995, 24, 1-6. [CrossRef]

7. Lee, J.G.; Thorson, E. The Impact of Celebrity-Product Incongruence on the Effectiveness of Product Endorsement. J. Advert. Res. 2008, 48, 433-449. [CrossRef]

8. McCracken, G. Who Is the Celebrity Endorser? Cultural Foundations of the Endorsement Process. Emot. Early Dev. 1989, 16, 315-349. [CrossRef]

9. Min, J.H.J.; Chang, H.J.J.; Jai, T.M.C.; Ziegler, M. The Effects of Celebrity-Brand Congruence and Publicity on Consumer Attitudes and Buying Behavior. Fash. Text. 2019, 6. [CrossRef]

10. Kong, Y.; Zhang, A. Consumer Response to Green Advertising: The Influence of Product Involvement. Asian J. Commun. 2013, 23, 428-447. [CrossRef]

11. Minton, A.P.; Rose, R.L. The Effects of Environmental Concern on Environmentally Friendly Consumer Behavior: An Exploratory Study. J. Bus. Res. 1997, 40, 37-48. [CrossRef]

12. Blasche, J.; Ketelaar, P.E. The Synergy in Green Persuasion: Green Celebrity Endorsers in Green Advertising: A Study of Brand-Endorser Congruence Effects in Green Advertising. J. Euromark. 2015, 24, 86-106. [CrossRef]

13. Erdem, T.; Swait, J.; Valenzuela, A. Brands as Signals: A Cross-Country Validation Study. J. Mark. 2006, 70, 34-49. [CrossRef]

14. Chin, P.N.; Isa, S.M.; Alodin, Y. The Impact of Endorser and Brand Credibility on Consumers' Purchase Intention: The Mediating Effect of Attitude towards Brand and Brand Credibility. J. Mark. Commun. 2019, 00, 1-17. [CrossRef]

15. Fan, Y. Ethical Branding and Corporate Reputation. Corp. Commun. 2005, 10, 341-350. [CrossRef]

16. Singh, J.J.; Iglesias, O.; Batista-Foguet, J.M. Does Having an Ethical Brand Matter? The Influence of Consumer Perceived Ethicality on Trust, Affect and Loyalty. J. Bus. Ethics 2012, 111, 541-549. [CrossRef]

17. Szmigin, I.; Carrigan, M.; O'Loughlin, D. Integrating Ethical Brands into Our Consumption Lives. J. Brand Manag. 2007, 14, 396-409. [CrossRef]

18. Arora, N.; Prashar, S.; Parsad, C.; Tata, S.V. Influence of Celebrity Factors, Consumer Attitude and Involvement on Shoppers' Purchase Intention Using Hierarchical Regression. Decision 2019, 46, 179-195. [CrossRef]

19. Ha, N.M.; Lam, N.H. The Effects of Celebrity Endorsement on Customer's Attitude toward Brand and Purchase Intention. Int. J. Econ. Financ. 2016, 9, 64. [CrossRef]

20. Kang, J.; Choi, W.J. Endorsed Sustainable Products: The Role of Celebrity Ethicality and Brand Ethicality. Cloth. Text. Res. J. 2016, 34, 303-319. [CrossRef] 
21. Muralidharan, S.; Xue, F. Influence of TV Endorser Types on Advertising Attitudes and Purchase Intention among Indian Rural Women: An Exploratory Study. Asian J. Commun. 2015, 25, 213-231. [CrossRef]

22. Erdogan, B. Celebrity Endorsement: A Literature Review. J. Mark. Manag. 1999, 15, 291-314. [CrossRef]

23. Spry, A.; Pappu, R.; Cornwell, T.B. Celebrity Endorsement, Brand Credibility and Brand Equity. Eur. J. Mark. 2011, 45. [CrossRef]

24. Dubinsky, A.J.; Nataraajan, R.; Huang, W.Y. The Influence of Moral Philosophy on Retail Salespeople's Ethical Perceptions. J. Consum. Aff. 2004, 38, 297-319. [CrossRef]

25. Trudel, R.; Cotte, J. Does It Pay To Be Good? MIT Sloan Manag. Rev. 2009, 50, 61.

26. Kirmani, A.; Shiv, B. Effects of Source Congruity on Brand Attitudes and Beliefs: The Moderating Role of Issue-Relevant Elaboration. J. Consum. Psychol. 1998, 7, 25-47. [CrossRef]

27. Kamins, M.A. An Investigation into the "Match-up" Hypothesis in Celebrity Advertising: When Beauty May Be Only Skin Deep. J. Advert. 1990, 19, 4-13. [CrossRef]

28. Kotler, P. Marketing Management, 7th ed.; Prentice Hall: Upper Saddle River, NJ, USA, 1997.

29. Crosby, L.A.; Gill, J.D.; Taylor, J.R. Consumer/Voter Behavior in the Passage of the Michigan container law. J. Mark. 1981, 45, 19-32. [CrossRef]

30. Dunlap, R.E.; Van Liere, K.D.; Mertig, A.G.; Jones, R.E. Measuring Endorsement of the New Ecological Paradigm: A Revised NEP Scale. J. Soc. Issues 2000, 56, 425-442. [CrossRef]

31. Doszhanov, A.; Ahmad, Z.A. Customers' Intention to Use Green Products: The Impact of Green Brand Dimensions and Green Perceived Value. SHS Web Conf. 2015, 18, 01008. [CrossRef]

32. Chuah, S.H.W.; El-Manstrly, D.; Tseng, M.L.; Ramayah, T. Sustaining Customer Engagement Behavior through Corporate Social Responsibility: The Roles of Environmental Concern and Green Trust. J. Clean. Prod. 2020, 262, 121348. [CrossRef]

33. Chang, H.; Zhang, L.; Xie, G.X. Message Framing in Green Advertising: The Effect of Construal Level and Consumer Environmental Concern. Int. J. Advert. 2015, 34, 158-176. [CrossRef]

34. Yue, B.; Sheng, G.; She, S.; Xu, J. Impact of Consumer Environmental Responsibility on Green Consumption Behavior in China: The Role of Environmental Concern and Price Sensitivity. Sustainability 2020, 12, 2074. [CrossRef]

35. Kao, T.F.; Du, Y.Z. A Study on the Influence of Green Advertising Design and Environmental Emotion on Advertising Effect. J. Clean. Prod. 2020, 242, 118294. [CrossRef]

36. Bamberg, S. How Does Environmental Concern Influence Specific Environmentally Related Behaviors? A New Answer to an Old Question. J. Environ. Psychol. 2003, 23, 21-32. [CrossRef]

37. Kang, J.; Hustvedt, G. Building Trust Between Consumers and Corporations: The Role of Consumer Perceptions of Transparency and Social Responsibility. J. Bus. Ethics 2014, 125, 253-265. [CrossRef]

38. Paul, J.; Bhakar, S. Does Celebrity Image Congruence Influences Brand Attitude and Purchase Intention? J. Promot. Manag. 2018, 24, 153-177. [CrossRef]

39. Uddin, S.M.F.; Khan, M.N. Green Purchasing Behaviour of Young Indian Consumers: An Exploratory Study. Glob. Bus. Rev. 2016, 17, 1469-1479. [CrossRef]

40. Mackenzie, S.B.; Spreng, R.A. How Does Motivation Moderate the Impact of Central and Peripheral Processing on Brand Attitudes and Intentions? J. Consum. Res. 1992, 18, 519. [CrossRef]

41. Phelps, J.E.; Hoy, M.G. The Aad-Ab-PI Relationship in Children: The Impact of Brand Familiarity and Measurement Timing. Psychol. Mark. 1996, 13, 77-105. [CrossRef]

42. Kumar, R.; Tripathi, V. Green Advertising: Examining the Role of Celebrity's Credibility Using SEM Approach. Glob. Bus. Rev. 2019, 1-20. [CrossRef]

43. Sheng, G.; Xie, F.; Gong, S.; Pan, H. The Role of Cultural Values in Green Purchasing Intention: Empirical Evidence from Chinese Consumers. Int. J. Consum. Stud. 2019, 43, 315-326. [CrossRef]

44. Amos, C.; Holmes, G.; Strutton, D. Exploring the Relationship between Celebrity Endorser Effects and Advertising Effectiveness: A Quantitative Synthesis of Effect Size. Int. J. Advert. 2008, 27, 209-234. [CrossRef]

45. Zhu, B. The Impact of Green Advertising on Consumer Purchase Intention of Green Products. SSRN Electron. J. 2012. [CrossRef]

46. Lafferty, B.A.; Goldsmith, R.E. Corporate Credibility's Role in Consumers' Attitudes and Purchase Intentions When a High versus a Low Credibility Endorser Is Used in the Ad. J. Bus. Res. 1999, 44, 109-116. [CrossRef]

47. Hartmann, P.; Apaolaza-Ibáñez, V. Consumer Attitude and Purchase Intention toward Green Energy Brands: The Roles of Psychological Benefits and Environmental Concern. J. Bus. Res. 2012, 65, 1254-1263. [CrossRef]

48. Singh, R.P.; Banerjee, N. Exploring the Influence of Celebrity Credibility on Brand Attitude, Advertisement Attitude and Purchase Intention. Glob. Bus. Rev. 2018, 19, 1622-1639. [CrossRef]

49. Coddington, W.; Florian, P. Environmental Marketing: Positive Strategies for Reaching the Green Consumer; McGraw-Hill Companies: New York, NY, USA, 1993.

50. Ohanian, R. Construction and Validation of a Scale to Measure Celebrity Endorsers' Perceived Expertise, Trustworthiness, and Attractiveness. J. Advert. 1990, 19, 39-52. [CrossRef]

51. Till, B.D.; Busler, M. The Match-up Hypothesis: Physical Attractiveness, Expertise, and the Role of Fit on Brand Attitude, Purchase Intent and Brand Beliefs. J. Advert. 2000, 29, 1-13. [CrossRef]

52. Goldsmith, R.E.; Lafferty, B.A.; Newell, S.J. The Impact of Corporate Credibility and Celebrity Credibility on Consumer Reaction to Advertisements and Brands. J. Advert. 2000, 29, 43-54. [CrossRef] 
53. Brunk, K.H. Un/Ethical Company and Brand Perceptions: Conceptualising and Operationalising Consumer Meanings. J. Bus. Ethics 2012, 111, 551-565. [CrossRef]

54. Matthes, J.; Wonneberger, A. The Skeptical Green Consumer Revisited: Testing the Relationship between Green Consumerism and Skepticism toward Advertising. J. Advert. 2014, 43, 115-127. [CrossRef]

55. Jain, S.K.; Kaur, G. Green Marketing: An Attitudinal and Behavioural Analysis of Indian Consumers. Glob. Bus. Rev. 2004, 5 , 187-205. [CrossRef]

56. Tucker, E.; Rifon, N.; Lee, E.; Reece, B. Consumer Receptivity to Green Ads: A Test of Green Claim Types and the Role of Individual Consumer Characteristics for Green Ad Response. J. Advert. 2012, 41, 9-23. [CrossRef]

57. Widaman, K.F. Common Factor Analysis Versus Principal Component Analysis: Differential Bias in Representing Model Parameters? Multivar. Behav. Res. 1993, 28, 263-311. [CrossRef] [PubMed]

58. Raubenheimer, J. An Item Selection Procedure to Maximise Scale Reliability and Validity. SA J. Ind. Psychol. 2004, 30, 59-64. [CrossRef]

59. Hu, L.; Bentler, P.M. Fit Indices in Covariance Structure Modeling: Sensitivity to Underparameterized Model Misspecification. Psychol. Methods 1998, 3, 424-453. [CrossRef]

60. Hair, J.F.; Anderson, R.; Babin, B.; Black, W.C. Multivariate Data Analysis: A Global Perspective. $2010 ; 7$.

61. Fornell, C.; Larcker, D.F. Evaluating Structural Equation Models with Unobservable Variables and Measurement Error. J. Mark. Res. 1981, 18, 39. [CrossRef]

62. Campo-Arias, A.; Oviedo, H.C. Propiedades Psicométricas de Una Escala: La Consistencia Interna. Rev. Salud Publica 2008, 10, 831-839. [CrossRef]

63. Barrios, M.; Bonillo, A.; Cosculluela, A.; Lozano, L.M.; Turbany, J.; Valero, S. Psicometría; UOC: Barcelona, Spain, 2013.

64. Anderson, J.C.; Gerbing, D.W. Structural Equation Modeling in Practice: A Review and Recommended Two-Step Approach. Psychol. Bull. 1988, 103, 411-423. [CrossRef]

65. Suki, N.M. Green Awareness Effects on Consumers' Purchasing Decision: Some Insights from Malaysia. Int. J. Asia Pacific Stud. 2013, 9, 49-63. 